УДК 821.161.2-93.09]-054.7:13

Варданян М. В., кандидат філологічних наук, доцент кафедри початкової освіти ДВНЗ «Криворізький державний педагогічний університет»

\title{
КАРТИНИ САКРАЛЬНОГО СВІТУ В ДИТЯЧІЙ ЛІТЕРАТУРІ УКРАЇНСЬКОЇ ДІАСПОРИ
}

У статті досліджується сакральна образність у різножанрових творах для дітей $i$ юнацтва письменників украӥнської діаспори XX cm., щзо формують християнсько-релігійний дискурс літератури загалом. Уся сукупність творів поділяється на дві групи. Перша група представлена біблійними легендами, друга - охоплює обряди та звичаї українців на християнські свята. У сакральній конщептосфері визначено власне сакральні та сакральнохтонічні образи.

Ключові слова: сакральний, конщептосфера, християнсько-релігійний дискурс, жанри літератури для дітей і юнацтва, література украӥнської діаспори.

The article deals with the sacred imagery in works of different genres for children and youth by Ukrainian Diaspora writers of the twentieth century that form the Christian religious discourse literature in general. The whole set of works is divided into two groups. The first group is represented by biblical legends, the second one covers rites and customs during the Ukrainian Christian holidays. In the sacred concept scope are defined their own sacred and sacral and chthonic images.

Key words: sacred, concept scope, Christian and religious discourse, genres of literature for children and youth, literature of Ukrainian Diaspora writers.

В статье исследуется сакральная образность в различных жанрах произведений для детей и юношества писателей украинской диаспоры XX в., которые формируют христианско-религиозный дискурс литературы в иелом. Вся совокупность произведений делится на две группы. Первая группа представлена библейскими легендами, втораяохватывает обряды и обычаи украинщев на христианские праздники. В сакральной конщептосфере определень собственно сакральные и сакрально-хтонические образы.

Ключевые слова: сакральный, конщептосфера, христианско-религиозный дискурс, жанры литературы для детей и юночества, литература украинской диаспоры. 
Релігійна тематика, поряд 3 історичною й патріотичною, $\epsilon$ однією 3 провідних у літературі для дітей і юнацтва української діаспори. Насамперед, поширення релігійно-християнського дискурсу у творчості емігрантів сучасна дослідниця авторської казки В. Кизилова, в унісон письменникамекспатріантам, пов'язує з нівелюванням християнських традицій і заміною їх на псевдоідеали в радянській дійсності [Кизилова:53]. Схожий погляд свого часу висловила В. Сулима, коли наголошувала, що Біблія i твори письменників української діаспори були під забороною за радянських часів, означених шляхом «псевдорозвитку нацуіональної культури, відділеної від релігї, позбавленої національних святинь та пам'яток християнської традиції» [Сулима 1998:8].

На противагу радянській ідеології червоною ниткою в періодиці та критичній літературі української діаспори проходила ідея про значення релігійного виховання, сфери якого, на переконання багатьох тогочасних дослідників, «в майбутньому стануть основою свідомого плекання українського побуту в намому родинному ци суспільному житі» [ДР 1964:1]. Тому, з огляду на важливість цих двох завдань (протистояння радянській системі та збереження українських християнських традицій), що ставили перед собою письменники діаспори, виник цілий пласт різножанрових творів для дітей і юнацтва, за виразом В. Маркуся, «просякнутих релігійно-національними мотивами» [Маркусь 1978:9].

Легенди, оповідання, казки, вірші, оди, молитви, пісні, п’єски для дітей друкувалися в журналах «Наше життя», «Соняшник», «Готуйсь», «Малий школяр», виходили в антологіях «На весь божий світ», «Декламатор», «Свшанзілля», «Золоте павутиння», «Сніжинки», «Джерело Марії», «Українське дошкілля» та збірках творів Л. Храпливої-Щур «Писанка українським дітям», «Вітер з України», «Вітер з України - 2», Р. Завадовича «З буднів у свято», В. Вовк «Чар-писанка». I хоча в означених виданнях опубліковано понад 100 художніх текстів для дітей релігійно-християнського спрямування, але цей перелік, звісно, не є повним та ще чекає свого упорядника. Наразі за мету цієї 
статті став розгляд картини сакрального світу українців через прочитання концептів сакрального в означених книжкових i періодичних виданнях для дітей, що не претендує на всеохопність та вичерпність.

У статті спираємося на дослідження, присвячені концептосфері сакрального (Т. Вільчинська), Біблії та літературі вітчизняних науковців 3. Лановик, В. Сулими й закордонних - Н. Фрая. А огляд розвідок критиків i діячів діаспори засвідчив, що для творів релігійно-християнського спрямування письменників української діаспори притаманно «нероз'єднане сплетення двох елементів національної свідомості й віри та релігійності» [Барагура 1996:62], у той же час патріотизм у них виступає «як істотна чеснота християнської релігї̈» [Маркусь 1978:8]. Ясна річ, що така стильова домінанта притаманна i художнім текстам для дітей та юнацтва, до аналізу яких доречним, вважаємо, застосування терміну «концептосфера сакрального». Адже, саме в сакральній концептосфері, що складається 3 концептів, наповнених релігійним смислом, відтворюються нашарування етнокультурних традицій, світобачення носіїв мови нації чи народу на певну ділянку релігійних знань [Вільчинська 2008:154]. Тим самим діаспорянці прагнули розкрити дітям змісти української християнської духовності в іï обрядових та звичаєвих виявах задля прищеплення релігійно-християнських цінностей українського народу. У такий спосіб у творах для дітей реалізувалися, 3 одного боку, сакральні форми спілкування Бога з людиною [Лановик 2006], a, 3 іншого, відбувався обряд ініціації, що передбачав навчання молодих людей основних міфів та звичаїв народу [Фрай 2010:133]. Відповідно всю сукупність творів для дітей і юнацтва на релігійно-християнську тематику, що охоплюють переважно Свято Миколая, Різдво та Воскресіння Христове, варто поділити на дві групи, що мали стати морально-етичними орієнтирами для молодої особистості.

Перша група творів презентована легендами та поезіями на біблійні сюжети про народження Ісуса та / або переслідування його родини Іродом («У тиху Різдвяну ніч», «Погоня», «Чому рожі мають колючки?» Р. Завадович, «Сніп пшениці», «Біфана», «Про пальму, що прагнула до зірок» Н. Наркевич, 
«Різдво» О. Стефанович, «Дід Єремія бідніший за мене...» О. Кобець, «Різдвяна казка» Л. Храплива-Щур), Богородицю («Джерело Марії» О. Цегельська, «Богородична трава» Н. Наркевич, «Легенда про колоски» В. Вовк), Розп 'яття Христа («Кліст» Н. Наркевич, «Ісусова сльоза» Р. Завадович), діяння Святого Христофора («Легенда про Христофора» В. Вовк, «Святий Христофор» Н. Наркевич), ангелів («Легенда про літаючі зорі» В. Вовк, «Чому іскриться сніг», «Найважча молитва» Н. Мудрик-Мриц). В основі цих текстів сюжет із Біблії, а біблійні герої стають безпосередньо персонажами. Тому варто вести мову про цілу типологію біблійних образів.

До виокремлення образності в Біблії вдавався у своїй книзі «Великий код: Біблія і література» канадський літературознавець Н. Фрай, який визначав п’ять типів біблійних образів - райські, пастирські, землеробські, міські та образність, пов'язана 3 людським життям як таким [Фрай 2010:215]. Ця класифікація може бути застосована і до аналізованих нами творів. Зокрема, героями вказаних легенд $\mathrm{i}$ віршів $\epsilon$ власне біблійні персонажі, які, за класифікацією Н. Фрая, розподілені як у Біблії на апокаліптичні, демонічні, аналогічні образи. До перших - віднесемо образи Бога, Ісуса, Богородиці, Святого Йосифа, ангелів, до других - образи пустелі, хижих звірів, пекельних сил (диявол, злий дух Вельзевул, цар Ірод, вояки-переслідувачі на конях, фарисеї, судові радники), а до аналогічних, так би мовити, проміжних, Аврама, Христофора, Рахіль, Марію Магдалину, Арона, Мойсея, Давида. Пастирська та землеробська образність презентовані через образи поля 3 пшеницею, хліба, саду, тварин (осла, корови, вола, ягнятка), райська представлена оазою 3 джерелом води, міська - образом Срусалиму, Віфлеєму, шляху чи дороги, - всі вони складають ідеальний світ. Цьому апокаліптичному світові протистоїть зло в особі Ірода, який переслідує родину Ісуса, та суддів, що прирекли Христа до розп'яття.

Із постаттю Ісуса, за Н. Фраєм, пов'язана символіка «доброго пастиря», або, як це бачимо в «Легенді про сухе дерево» В. Вовк. У той час Тіло Христове в «Легенді про калиновий кущ» В. Вовк - $є$ «метафорою зцілення» (Н. Фрай). 
Також символічними в цьому плані $є$ образи вінка 3 білих троянд на Ісусові («Біфана» Н. Наркевич) та стоп Мужа з Назарету, «з-під яких вицвітали ... білі нарцизи» («Легенда про калиновий кущ» В. Вовк), що уособлюють праведні справи для людей. Натомість образи вінка 3 колючок («Кліст» Н. Наркевич) та стоп Христа, що «багрили пил дороги» («Легенда про калиновий кущ» В. Вовк) символізують спокуту Христа за людські гріхи. Тому наскрізним мотивом цієї групи творів є ідея спасіння душі людини та суспільства, запозичена з Біблії.

Для ствердження віри в Бога та Божого Сина до сюжетної канви, за аналогією до Біблії, вводяться мотиви творення ними чудес (за ніч виросла пшениця - «Сніп пшениці» Н. Наркевич, бур'ян перетворився на квітку «Богородична трава» Н. Наркевич, одужують каліки і невиліковні - «Погоня», «Ісусова сльоза» Р. Завадович, освячується шлях праведним душам - «Легенда про літаючі зорі» В. Вовк тощо). Також у художніх текстах для дітей подаються різні види спілкування з Богом. Різновиди цих сакральних форм, наявних у Біблії, визначила 3. Лановик у своєму дослідженні про біблійну герменевтику [Лановик 2006:31-32]. Так і в художній формі творів цієї групи до форм спілкування дитини з Богом відносимо, за аналогією до З. Лановик, видіння («Легенда про Христофора», «Легенда про колоски» В. Вовк, «Святий Христофор», «Біфана» Н. Наркевич), що супроводжуються у текстах сяйвом, знаки («Різдвяна ніч», «Стара церква» В. Вовк, «У тиху Різдвяну ніч» О. Цегельська), притчі («Легенда про сухе дерево» В. Вовк), пророцтва («Кліст» Н. Наркевич), ангельській повідомлення («Найважча молитва» Н. Мудрик-Мриц). У такий спосіб сповідуються головні християнські цінності праведності, святості, мучеництва, та біблійні заповіді - віри в єдиного Бога, любові до ближнього, служіння їм.

В іншій тематичній групі - розкриваються українські християнські традиції та обряди на Новий Рік, Святого Миколая, Різдво Христове, Великдень, Святого Андрія, Святого Юрія, Зелені святки. У цьому календарі релігійних свят особлива роль належить таким християнським звичаям українців: молитися, у т.ч. за Батьківщину («Молитва» К. Перелісна, «Ангел на 
Землі», «Ангельські очі», «Молитва за маму», «Ранішня молитва», «Марусина молитва», «Благослови нас, Божа Мати!» Р. Завадович, «Три матусі» Л. Полтава, «Три матері» В. Переяславець, «Молитва українських дітей» I. Савицька, «Найважча молитва» Н. Мудрик-Мриц, «За здоров’ячко матусі» О. Цегельська); відвідувати богослужбу $i$ храм, який має стати основою світобудови дитини («У церковці» Р. Завадович, «Стара церква» В. Вовк); посівати на Новий рік («3 Новим Роком» Л. Храплива-Щур); очікувати дарунків від Миколая за гарні вчинки («Лист до Святого Миколая» Л. ХрапливаЩур, «Святий Миколай і пастушок» В. Вовк, «Перед Різдвом у лісі» Г. Черінь, «О хто, хто Миколая любить» І. Савицька); готуватися до свята Різдва $i$ Великодня («На Святий вечір» О. Цегельська, «Різдвяний дарунок для ”гаски”», «Страсний Четвер» Н. Наркевич, «Івась-Мудрась» С. Кузьменко); носити вечерю на Різдво, частувати кутю, заносити дідуха з колосся, колядувати $з$ вертепом, піснями, зіркою («Святвечір», «Коляда в діда Миколи» І. Боднарчук, «На Свят-вечір», «Ми йдемо колядувати» К. Перелісна, «Колядники» Р. Завадович, «Різдво», «Перший дар», «Новацьке Різдво» Л. Храплива-Щур, «Гість із далекої країни» О. Цегельська); ворожити на Святого Андрія («Вечір під Святого Андрія» Л. Храплива-Щур); запалювати периу весняну ватру на Святого Юрія - опікуна Запорізьких козаків і новаків («Святий Юрій» Л. Храплива-Щур, «Святий Юрій» Р. Завадович); розмальовувати писанки («Киця-писанчарка» Н. Наркевич, «Зайчик-збиточник» Вуйко Квак, «Великодні писанки» Л. Полтава, «Писанка» К. Перелісна, «Найкраща писанка» I. Савицька, «Маринчина писанка» С. Кузьменко, «Писанка» Н. Мудрик-Мриц, «Одарочка малює» Л. Храплива-Щур), освячувати $\ddot{x}$ на Великдень («Легенда про писанку Свят-Миколи» В. Вовк, «Що одна писанка наробила» П. Волиняк), відвідувати близьких («На Великдень до бабусі» Л. Храплива-Щур), обмінюватися та цуокатися писанками («Пригоди писаночки» Л. ХрапливаЩур, «Легенда про писанку Свят-Миколи» В. Вовк), співати гаївки («Гагілка» Н. Мудрик-Мриц); прикрашати зеленню помешкання та шанувати померлих («Зелені свята» Л. Храплива-Щур). 
Твори цієї групи мають характерні стильові риси, пов’язані 3 певним святом, а в сакральній концептосфері, слідом за Т. Вільчинською, визначаємо власне сакральні та сакрально-хтонічні образи. Як твердить дослідниця, такий розподіл зумовлений діалектикою сакрального: «Сакральним породжені добрий дух $i$ злий, Бог $i$ сатана, свящуеник $i$ чаклун, які можуть урятувати $\check{u}$ занапастити. Отже, у межах сакрального на одному полюсі обов'язково має бути священне, на іншому демонічне» [Вільчинська 2008:153].

Основними репрезентантами перших - власне сакральних - $\epsilon$, передусім, концепти на позначення Бога та всього святого. За аналогією до класифікації Т. Вільчинської, образи в цій групі поділяємо на загальнорелігійні (Бог, Ісус, Богородиця, Святий, ангел, душа, рай), морально-етичні (віра, спасіння, любов до ближніх, тягар хреста, жертва, праведність, благословення, слава й пошана, надія), обрядові (храм, церква, богослужба, молитва, хрест, дзвіниця, капличка, лампадка, іконостас, писанка, паска, свічники, свічки, ладан, розп’яття, святвечірня, Свангеліє, ворожіння, таїнство), а також додамо астральні (зоря, небо, зірки, зорі, місяць).

До хтонічної образності належать концепти на позначення зла i демонічних сил. Вони презентовані образом диявола, що є ядерним концептом, а його предикатами стають концепти - дідько, Арідник, Ірод, лютий цар, кати, злі духи, пекельні сили, чорти, Антипко, гріх, святотатство. 3 цього приводу слушно зауважує Т. Вільчинська, що «усі вказані ментальні величини репрезентовані в мові через відповідні лексеми - назви основних богословських понять $і$ біблійних персонажів, таїнств, найменування Небесної ієрархї, лексику на позначення елементів цеерковного календаря, предметів богослужіння, церрковної ієрархї̈, назви храму $і$ його частин, свящуеницьких обладунків, лексику християнської моралі, а також різну демонолексику» [Вільчинська 2008:156].

У такий спосіб дітям подаються уявлення про рай / пекло, світло / тьму, сяйво / морок, смерть / воскресіння, Бога, святих, ангелів / диявола, чортів. Зокрема, у самій назві п’єски Л. Храпливої-Щур «Антипкові пригоди, або 
У День Св. Миколая» закладений такий розподіл на демонічне / святе. У принципі, як і в інших творах про Святого Миколая, серед яких «Перед Різдвом у лісі» Г. Черінь, «Миколаю, не забудь!» Р. Завадовича, «Лист до неба», «Легенда про Святого Миколая» Н. Наркевич, «Свято-Миколаївська сценка», «В День Святого Миколая», «Пятачок», «Пригода янголятка» Л. ХрапливоїЩур, «Святий Миколай і пастушок» В. Вовк. Тут образна система поділяється на три групи, адже до героїв творів долучаються і українські діти в еміграції.

Із сакральним світом пов'язана перша група героїв - Святий Миколай, янголи, що складають світ, в якому можливо диво. Друга група - діти, які, в очікуванні чудес (подарунків чи помочі), пишуть листи Миколаю Чудотворцю, котрий заслужив свій сакральний статус справами, пов'язаними 3 допомогою людям - бідним і знедоленим. Вони висловлюють пошану Святому, просять благословення, описують свої гарні вчинки.

Колізія у творах розгортається навколо свята Миколая, котре прагнуть зірвати персонажі третьої групи, а саме: власне чортенята, Старший чорт, Антипко, чортики Круть і Хвиць, які хоча і презентують хтонічно-сакральний світ, але подаються в комічному світлі. 3 ними пов'язаний образ пекла, наближений до світу, зрозумілий дітям, 3 коміксами, телевізором, невихованістю («Антипкові пригоди, або У День Святого Миколая» Л. Храплива-Щур). Контрастно до діянь пекельних сил подаються добрі справи Святого Миколая та ангелів на небі. Цим автори втілюють провідну ідею у своїх творах - допомагати тим, хто цього потребує - бідним, знедоленим, старшим і меншим: «Бо найбільше щзастя у житті - цуе творити добро» («Легенда про Святого Миколая» Н. Наркевич).

У дусі християнських традицій та народних звичаїв українців у творах сповідується шанобливе ставлення до представників тваринного світу, якими $є$ традиційні образи звіряток, пташок із народних казок та / або біблійних сюжетів (зайчик, лисичка, вовчик, Бровко-песик, курчатко, киця, ягнятко та ін.). У казках і віршах («Перед Різдвом у лісі» Г. Черінь, «Різдво у лісі» І. Савицька, «Ялинка для звіряток», «Киця-писанчарка» Н. Наркевич, «Подарунок» 
Р. Завадович, «Що одна писанка наробила» П. Волиняк, «Зайчик-збиточник» В. Квак, «Писанки Оксани», «Що роблять звірята», «Великодня пригода», «Пригоди писаночки» Л. Храплива-Щур) письменники закликають співіснувати в гармонії з тваринами - любити, доглядати, охороняти їх від лиха, тоді і вони віддячать любов'ю і вірністю людям. Тому звірятка стають безпосередньо учасниками дійств на свята Різдва та Великодня, а, отже, частиною сакрального.

Водночас провідною, органічною складовою сакрального у творах Різдвяного та Великоднього циклів виступає свято. Ядерним у цих текстах $\epsilon$ концепт святий, а приядерними - святість, Святий, Святі, святе, свячене, свячена вода, свячена юрба, святковий стіл, Свят-Вечір, свят-вечірня їжа, свята ніч, святі скитальці, Свята Родина, Господнє Свято. Ці сакральні концепти розкриваються через сам процес святкування та обряди (таїнство вечері на Різдво - «Перша ялинка», «Щасливий Святий вечір» Н. Наркевич, Великдень «Гагілка» Н. Мудрик-Мриц, «Пригоди писаночки» Л. Храплива-Щур), атмосферу свята («Різдвяна легенда» В. Вовк, «Ялинка для звіряток» Н. Наркевич, «Різдво у лісі» І. Савицька, «Різдво» О. Стефанович, «Христос Воскрес!» В. Ворскло, «Христос Воскрес», «Христос Воскрес, моя дитино!» К. Перелісна, «Христос Воскрес!» І. Савицька, «Великдень», «Великдень милий гість» Р. Завадович, «Грайте, радісні дзвони» Л. Мосендз, «Великодні дзвони», «Воскресний дзвін», «Зірка» Л. Храплива-Щур, «Великодні писанки» Л. Полтава) та образи - біблійні («Різдвяна подорож» Л. Храплива-Щур), персоніфіковані (колядки у «Колядка» Н. Мудрик-Мриц, «Ходить Колядка...» Р. Завадовича та писанки «Пригоди писаночки» Л. Храплива-Щур), таїнства вечері, сяйва зірок (блискуча зоря, світло зірок, сліпуче світло).

Образи дзвонів, великоднього передзвону, весни, хороводів («Великдень» В. Ворскло, «Великдень!» М. Щербак, «Великдень» Р. Завадович) є своєрідним «оспівування весни, квіття, зелені, тепла, пробудження життя, які повнотою гармонізують з мотивами Великодня $і$ воскресіння - повстання $з$ гробу» [ВД 1968:8]. Тому до творів Великоднього циклу вкраплюються образи кам'яного гробу, Ісуса в гробі, кривавих сліз, тернового вінка, гори Голгофи, 
тягаря хреста, темно-червоного хреста, крові, цвяхів. Ці великодні мотиви символічно поєднані, за слушним зауваженням о. Анастасія Г. Великого, «з історією украӥнської людини і украӥнської землі новіших часів, ї̈ недолі національної $i$ державної» [ВД 1968:8]. Ці твори - то своєрідна молитва за Україну.

Варто додати, що такі інтенції спостерігаються і у творах Різдвяного циклу («Погоня», «Різдво в таборі 1948 р.» Р. Завадович, «Джерело Марії», «У тиху Різдвяну ніч» О. Цегельська, «Різдвяна подорож», «Надворі темніє...» Л. Храплива-Щур), де центральним також $є$ образ пануючого в Україні «кривавого, червоного Ірода», що уособлював тоталітарний режим, а провідна ідея втілюється в сподіваннях про його повалення та відродження України, їі державності, що грунтуватиметься на українських християнських цінностях.

На останок підсумуємо, що у творах для дітей і юнацтва сформовано сакральну картину світу українців, в основі якої духовність, релігійність, вічні цінності, глибокі моральні засади життя. Тож до основних рис сакрального у творах для дітей української діаспори віднесемо святість і духовність, що розкриваються через образи Месії, Божої Матері, Святого Миколаю, ангелів, храму, дитини. У такий спосіб за допомогою біблійних образів, символів і сюжетів письменники української діаспори відтворили основні релігійні концепти віри, що поєднувалися 3 почуттями любові до України.

Охопленні теми про Бога, Ісуса, Богородицю і життя Святих, а також обряди та звичаї українців на християнські свята, мали не лише просвіти дітей iз засадами християнства, а й вплинути на формування їхнього духовного світу. Серед таких моральних орієнтирів - вірування в Бога, збереження християнських традицій українців, плекання родинних цінностей, любов до ближніх, молитва за Батьківщину, множення добра.

\section{БІБЛІОГРАФІЯ}

Барагура 1996 - Барагура В. Де Ти, Христе, в день Твого світлого Воскресіння // Володимир Барагура. Зустріч 3 русалкою у хвилях океану. 
Крихти 3 мого життя - дійсність і вигадка. - Джерсі-Сіті : Свобода, 1996. C. $62-63$.

ВД 1968 - Великодні дзвони : антологія новішої української великодньої поезії / Упорядник Г. Г. Кінах. - Рим, Італія : Видавництво О. О. Василіян, 1968. - 239 c.

Вільчинська 2008 - Вільчинська Т. Концептосфера сакрального в сучасній науковій парадигмі [Електронний ресурс] / Тетяна Вільчинська // Теорія і практика викладання української мови як іноземної. - 2008. - Вип. 3. - С. 150159. - Режим доступу до статті : http://philology.lnu.edu.ua/teoria_praktyka_ukr_ mova/vyp_03_2008/25.\%20Vil'chynska.pdf.

Кизилова - Кизилова В. Християнсько-релігійний дискурс української прозової літературної казки другої половини XX - початку XXI століття [Електронний ресурс] / Віталіна Кизилова // Наукові виклади. - С. 53-56. Режим доступу до статті: file:///C:/Users/User/Downloads/Mandriv_2012_5_12.pdf

Лановик 2006 - Лановик 3. Біблійна герменевтика: становлення, методологія (символіко-алегоричний аспект літературознавчого дискурсу) : Автореф. дис. ... д-ра філол. наук : 10.01 .06 / З. Б. Лановик ; НАН України, Ін-т літератури ім. Т. Г. Шевченка. - К., 2006. - 36 с.

Маркусь 1978 - Маркусь В. Передмова // Роман Завадович «З буднів у свято» : збірка віршів на релігійну тему / Передм. Василя Маркуся. - Чикаго : Ставропігія, 1978. - С. 7-13.

ДР 1964 - Дитяче Різдво // Наше життя, 1964. - Ч. 11. - С. 1.

Сулима 1998 - Сулима В. Біблія і українська література : навчальний посібник / Віра Сулима. - К. : Освіта, 1998. - 400 с.

Фрай 2010 - Фрай Н. Великий код: Біблія і література / Нортроп Фрай ; переклад з англ. Ірини Старовойт. - Львів : Літопис, 2010. - 362 с. 